\title{
Grundtvig of Denmark \\ - (Still?) a Guide to Small Nations \\ Some Grundtvigian Reflections on the Scottish \\ Independence Referendum Debate
}

\author{
Jack Dyce
}

In September of 2014, the majority of Scots voted "No" in a referendum to determine whether or not Scotland should become a sovereign nation independent of the United Kingdom. This essay uses Noëlle Davies' 1944 pamphlet Grundtvig of Denmark. A Guide to Small Nations to reflect upon the Scottish independence debate and consider Scotland's post-referendum future. Davies was a Welsh nationalist in the post World War II period; she and her husband attempted to import many of the Grundtvigian ideals they came to embrace during their experiences at the International People's College in Elsinore, Denmark. Written as it was during a time of post-war nationalist fervour, the pamphlet therefore provides a unique connection point between the thinking of Grundtvig about Denmark as a small nation and the thinking of contemporary Scottish nationalists. Although leaders in the referendum debate were very careful not to engage directly issues of culture, ethnicity, and language, the general populace openly talked about what it means to be a Scot; therefore, the people demonstrated a general feature of nationalist movements worldwide. Grundtvig sought cultural inroads to national unity and, interestingly, Scottish pro-independence leaders in general argued for the benefits of independence to Scottish life, which brought about renewed interest in Scottish music, art, and language, both Gaelic and Germanic forms of Scots. And now that Scotland has voted to remain part of the United Kingdom, Scots might learn important lessons from Grundtvig about what it means to be a small but productive member of a network of nations.

The Scottish Referendum Act of 2013 stated, "A referendum is to be held in Scotland on a question about the independence of Scotland. The ques- 
tion is - 'Should Scotland be an independent country?'” The act established legislative authority for a poll to determine whether or not Scotland should become an independent nation (SIRA 2013). The referendum was held on 18 September 2014, and the majority of Scots voted "No"; the referendum did not pass.

Seventy years earlier, Noëlle Davies, a scholar and campaigner for Welsh nationalism, published the pamphlet Grundtvig of Denmark. A Guide to Small Nations. Davies wrote it in the context of the closing stages of World War II when minds were turning to post-war challenges.

Davies, originally from Ireland, had married an economist, David James Davies, in 1925. They had met at the International People's College in Elsinore, Denmark, where their view of the relationship between socialism and nationalism changed to a view of their mutuality. The couple became active in the Welsh Nationalist Party (now Plaid Cymru) when it was founded in 1925. In 1932, they bought Pantybeiliau mansion in Monmouthshire where they attempted, unsuccessfully, to establish a folk school broadly upon Grundtvigian principles. Davies' pamphlet testifies to the extent to which the couples' learning about Grundtvig's thinking, the folk high school movement, and Danish social, political, and cultural life had strongly influenced how they understood the movement for home rule and national development in Wales. The couple remained active in Plaid Cymru throughout their lives (Archifau Cymru n.d.).

This article's inspiration comes from my own reading of Noëlle Davies' pamphlet. In the footsteps of Davies, I seek to ask whether and how the thinking of Grundtvig, not least around his sense of Denmark as a small nation, resonates with contemporary Scottish questioning and offers us insights by which we might reflect upon the Scottish independence debate. In the light both of fragmentation of the former Soviet Union and the Balkans and of movements throughout the world for regional or national political autonomy, the question of the autonomy of smaller nations has been the subject of fresh research interest. ${ }^{1}$

1 The most common questions are of international relations and defence, e.g. Archer and Nugent, eds. 2002; Baehr 1975; Bailes and Thorhallsson 2013; Bailes et al. 2013; Grímsson 2008; Hey 2003; Kristjansson and Cela 2011; and Olafsson 1998. Other aspects considered include structural and constitutional questions, as in Laffan 1997, Panke 2010 and 2011 and Thorhallsson 2006 and economic issues, as in 
Nationalism in Denmark 1800s, Wales 1940s, and Scotland 2014

The contexts of Grundtvig's Denmark and Davies' Wales differ of course from the Scottish context. Davies wrote about how in Grundtvig's Denmark, the absolute monarchy was coming to an end, the feudal system in agriculture was shifting, industrialisation and natural resources were lacking, and "vigorous intellectual life" and popular education were wanting (Davies 1944, 6). Davies' Post-war Britain faced similar challenges of economic and physical recovery and of constructing a society that would not simply revert to how things once had been. In Scotland today the debate over dependence has framed challenges either as opportunities or as threats to present stability, depending upon the point of view. Nonetheless, the question in all three times and places concerns how nations shape values at a particular moment of awakening and decision-making.

The notion of "awakening" is recurrent in Grundtvig's thinking, whether in terms of his own spiritual and theological understanding or, as in Brevveksling mellem Norrejylland og Christianshavn (US IV, 228-236) or Skov-Hornets Klang mellem Skamlings-Bankerne (GEEG Stk. 4), the arousing of the nation and its leaders from the slumber of indifference to Denmark's plight. Common to many national movements, of course, is the call for (re)awakening. Consider, for example, Estonian nationalism (Raun, 2003), Latvian awakenings of the 1850s-80s, 1918 and 1987-91 (Kruk and Chakars, 2010), and the Risorgiomento in Italy (Patriarca and Riall, 2011).

Davies refers to Grundtvig's efforts to stimulate a new spirit in Denmark, and she quotes Ingemann's "What Denmark was, it can be again - our fathers' spirit is still alive" (Davies 1944, 10) in order to assert that such a revival was needed in Wales. And even though the Scottish pro-independence campaign relied explicitly less upon the theme of rediscovery of nationhood, few can doubt that ideas about national awakening were present as subtexts of the debate. When Scottish Government proposals for independence began with the assertion that "Scotland is an ancient nation" (Scottish Government 2013b, online), thoughtful listeners heard

Katzenstein 1985; Keating and Harvey 2014; Thorhallsson and Kattel 2012. Many of these research articles reflect also on the concept of the small nation-state. 
the complementary themes of looking back to an old history and forward to when, in the words of $O$ Flower of Scotland, the country might "be a nation again" (Williamson, online). When the devolved Scottish Parliament sat for the first time, its chairperson declared that the old pre-Union Parliament of Scotland had been "reconvened." Denmark in Grundtvig's day, Wales in Davies' time, and the Scotland of today all encountered constitutional questions that rested upon underlying beliefs about the national spirit, tropes of national awakening, and themes about the search for national meaning and purpose.

Some scholars have regarded Grundtvig's approach to the role of nations and to national identity as somewhat essentialist (Rerup 1993). In his view nations were part of the divine ordering of the world. In Folkelighed of 1848, Grundtvig writes, "Byrd og Blod er Folke-Grunde, ikke Luft og mindre Staal" (PS VII, 97). At first sight, this line appears to affirm a decidedly ethnic view of the folk, and Vind (Vind 1999) indeed has argued that Grundtvig's nationalism has an ethnic root. But Lundgreen-Nielsen counsels us not to read the phrase as a reference to genetic or racial purity but rather as a poetic reference to the familial affection and respect that ought to be borne towards one's forebears (Lundgreen-Nielsen 1997, 89). Grundtvig addressed perennial question of who belongs to a nation and who, even if resident, does not when he wrote:

What is a people? (...) Is it the nose or the mouth that gives it away? (...) They belong to a people who think they do, those who hear the mother tongue, those who love the fatherland, the rest are separated from the people, expel themselves, do not belong (Østergaard 2006).

In Folkelighed (1848), he added,

To a nation they belong

who consider themselves so

with an ear for their language

and fire for their country.

(Thyssen 1983, 349)

Yet, Grundtvig seems ambivalent at best. He was reluctant to afford Goldschmidt, a Jewish Dane, more than the status of a guest, even though he 
acknowledged Goldschmidt to be a better writer in Danish than other Christian Danish writers (Bredsdorff 1974, 40). This ambivalence suggests Grundtvig had not so easily resolved the tensions between civic, ethnic, and cultural notions of national belonging.

Both sides of the referendum debate over Scottish independence attempted to set the argument within a civic rather than an ethnic frame. Though the Wales, Scotland, and Demark of the past were demographically amongst the more homogeneous nations, these nations are today seeing increasing ethnic and cultural plurality, and tensions surround the place that immigration plays in nationhood and national identity. Those of Scottish ancestry or those born in Scotland or with other significant connections (and who therefore may well consider themselves and be considered by others to be Scots) were nonetheless ineligible to vote in the referendum if they were not registered on the Scottish electoral rolls (and therefore normally residing in Scotland). Although this requirement caused some disquiet, protest, and even legal action, both sides in the independence debate followed the principle in order to present Scotland as modern, progressive, and inclusive. Both sides wanted to avoid ethnocultural representations, which they held to be backward looking and narrow-minded.

This effort by leaders of the debate worked against the sentiments of the wider Scottish public who often emphasized ethnocentric and cultural indicators of national identity (Leith and Soule 2012). Referendum rhetoric was dominated by a civic tone, though not without references to national pride (which undoubtedly carried historic dimensions) or to historical and cultural contexts (Smith 1991; Yack 1999). However much political leaders might have sought to represent the nation as a civic entity, the political case drew upon distinctions between the proposed nation-state and other configurations, the suggestion being that Scotland's situation was fundamentally different from its neighbours'.

A.D. Smith defines nationalism as "an ideological movement for attaining and maintaining autonomy, unity, and identity on behalf of a population deemed by some of its members to constitute an actual or potential 'nation'" (Smith 1991, 73). Even if an imagined (even fictive) kinship is tacitly asserted, a focus on cultural allegiance allows outsiders to join, assimilate and belong (Smith 1991, 24, n.17). A nation as community and 
as culture finds its natural expression in the exercise of political autonomy, where the cultural nation matches the political nation.

Claims of national autonomy arise from two different groups, each starting from a different principle. First, the essentialist group holds that a particular people and territory is a nation that binds together a sociohistorio-cultural way of life with an economic system; therefore, it ought to exist and be recognised as an independent state. And second, the national identity camp holds simply that identity is strongly linked either to the nation's separate existence as a sovereign state-its independent workings—or to its very claim to such sovereignty.

Denmark has a long history as a state, either lately as a nation-state or previously as a multi-national state. As Østergaard asserts, "Danishness has always been intimately linked with its existence as a sovereign state" (Østergaard 2006, 85). Scotland, though not a nation-state like Denmark, with substantial sub-state devolved powers and both late and long-standing civic institutions of its own, nonetheless has preserved a strong sense of identity through aspects of its own governance.

The Scottish National Party (like Plaid Cymru, its counterpart in Wales) might well be thought to belong to the first, essentialist camp. The Scottish Government White Paper on the constitutional aspects of independence referred repeatedly to the Scottish people as "sovereign" (Scottish Government 2013a, 2, 7, 13, 15-16) with the right to self-determination. This principal White Paper set out the arguments for independence, but it did not focus on the sovereignty argument. Instead, in passages like the following one, it identified many broad benefits and gains that would result from independence:

If we vote Yes, we take the next step on Scotland's journey. We will move forward with confidence, ready to make the most of the many opportunities that lie ahead. The most important decisions about our economy and society will be taken by the people who care most about Scotland, that is by the people of Scotland. The door will open to a new era for our nation. (...) We, the people who live here, have the greatest stake in making Scotland a success. With independence we can make Scotland the fairer and more successful country we all know it should be. We can make Scotland's vast wealth and resources work much better for everyone in our country, creating a society that reflects our hopes 
and ambition. Being independent means we will have a government that we choose - a government that always puts the people of Scotland first (Scottish Government 2013b, 1).

The debate was rarely framed as a simple imperative that each nation ought to be a state in its own right. Stephen Maxwell, the son of a left-wing Scottish nationalist intellectual, wrote recently in a re-published volume of his late father's essay, "The belief that a nation should be independent simply because it is a nation (...) is an intellectual dead-end which, thankfully, few in the SNP [The Scottish National Party] subscribe to these days" (Maxwell 2013, 13). Yet, a pro-independence campaign is inevitably a coalition of both camps, of those who argue on the basis of alleged sovereignty and of those who see particular socio-political-economic outcomes. Perhaps the pragmatic constitutional question was and remains to be: How much independence in decision-making and freedom of action is necessary for Scotland to be the nation it wants to be?

The second, national identity camp claims that, being a cultural community, the nation requires political autonomy in order to flourish and to protect its culture. Basque, Catalan, Québécois and Welsh nationalisms, for example, have argued for independence or autonomy on the grounds that such constitutional change is a necessary element in protecting, sustaining, and nurturing the distinctive culture of the society, including its language.

Language was certainly a crucial point of national identity for Grundtvig. Allchin points out that, along with his focus on the mother tongue, "the persistent vitality of the Welsh language" was something that Grundtvig "observed with a certain surprise" (Allchin 1992, 34). This itself made Grundtvig think more highly of the Welsh nation and its confidence in its culture (Davies 1944, 37). Grundtvig's attachment to the Danish language draws upon a belief rooted in the thinking of Herder about the relationship between a language and a volk. Grundtvig's concept of folkelighed with the national language at the core, a leaf of Det Danske Fiir-Klover ( $V U$ IV, 145-83) reflects Herder's influence. And Grundtvig responded to the use of German especially in Slesvig but also in higher Danish society by defending the Danish tongue. The effort itself became emblematic of the need to safeguard Danish culture within Denmark itself. He regarded educational use of Latin as part of a system that was dead and elitist, and 
in his roles as poet and philologist, Grundtvig cherished the lexicon and speech of the folk in the mouth of ordinary Danish people.

Nationalist movements today connect threats to language with threats to culture and national identity. Jordi Pujol, for example, wrote that the Catalan people are "threatened by the loss of a sense of cohesion and of the deep-rooted individual and collective identity, subjected to an alienating situation as a people" (quoted in Guibernau 2004, 142), not least in a context where Spanish / Castilian language promotion and Catalan suppression was a major government policy in the period of Franco. Welsh nationalists, as Noëlle Davies affirmed, found linguistic bases for their promotion of nationhood and defence of culture, because language and culture distinguished them most distinctly from England and the wider United Kingdom. Such issues remain significant in the Welsh context today. Are they, however, significant in a Scottish context also? At first sight, it might appear not. Scots Gaelic is spoken by relatively few Scots and, while it might be cherished for its relationship to Scottish national identity, the language does not specifically define Scottish-ness for the simple reason that so many born and bred Scots do not speak it. Also unclear is the situation of Scots as a Germanic language in the line of Old Northumbrian. Many Scottish people speak something more of a Scots English than Scots itself. Yet, one cannot deny the importance of Scottish words and expressions in marking the speaker as Scottish, whatever their ethnicity or location.

One movement afoot in Scotland that seems Grundtvigian in its efforts is the so-called Scotticisation of Scottish education and its de-Anglicisation. There is a growing acceptability of Scottish words and phrases and accents in the public contexts of education, broadcast media, and formal speech. In Kidspoem / Bairnsang, the Scots poet Liz Lochhead renders her poems about a child's school experience in both Scots and English. She pointedly and humorously observes the once clearly-drawn realms of the private home and the public school (Lochhead 2003), the first a folkelig space, in Grundtvigian terms, the second alien to its own culture. Lochhead's observations trigger thoughts about the right to speak in public just as one speaks at home (though recognising that each has its own register) as an important aspect of building the self-confidence and identity of a people and its nation. This is a point no less true today than when Peter Hiort Lorenzen of Haderslev persisted in speaking Danish in the 
Schleswigian citizen's assembly in 1842 (Simon 1998). And even though the Scottish independence debate did not foreground language questions (for Gaelic has already sufficiently devolved in use), Scots and Scots-English language status and usage are part of the re-affirmed and developing Scottish national identity, self-assurance and pride, that brought Scottish independence to be a possibility worthy of imagining.

Cultural and political nationhood, of course, do not have to coincide, though nationalism often claims that they do. Two contexts, in particular, created desire to bring the cultural and the political together through an independence movement. One was a perception of threat. Grundtvig saw a Germanification of Danish cultural and political life, especially amongst elites, a danger he identified in Lykøskning til Danmark med det danske dummerhøved og det danske høiskole 1847 (UV VII, 181-270). Davies observes that Grundtvig doubted, on practical grounds, that the Danish State was then "particularly Danish in cultural terms. As for their national language (...) many of them [the Danish elite] were inclined to be ashamed of it and to look on it as the unpolished speech of an inferior class" (Davies 1944, 6-7). Influenced by a Herderian affirmation of a nationalism of the people rather than a Hegelian nationalism of the state (Korsgaard 2014, 62), Grundtvig attached great significance to the nation as a cultural community. The state could become an "empty and dead" thing, static and destructive of the liveliness of the people (Thaning 1972 , 104). Yet, sovereignty was a means by which people might protect their special cultural identity and facilitate conversations about what is important to them (Korsgaard 2011, 17). Grundtvig knew that formal political sovereignty offers in itself no guarantee of cultural safeguarding, so he promoted folk movements to defend Danishness and revitalise Danish culture. Where there is no threat to culture, nationalists and others concerned for the distinctive culture of the nation work to promote cultural flourishing. For example, Scott argues that "it is because we [the Scots] have a distinctive, diverse and valuable national culture that we need independence to fulfil our potential [my emphasis] and give expression to our identity" (Scott 2003, 318). Scott's sentiment finds validity in the point that beginning in the mid-nineteenth century and extending throughout the twentieth century Scotland has long been on a road of cultural revival through an extended process of de-Anglicisation of Scottish life, not least of speech and education and culture in Scotland, a process 
paralleled throughout the "Celtic Fringe" and beyond (Whalen 2007). The establishment of Scottish cultural organisations (albeit with financial and organisational challenges), the renewed commitment to the Gaelic language and culture, the resurgence in Scottish folk music and storytelling, the renewed media interest in Scots culture-these are some recent developments. Devine asserts that "a new vitality in many aspects of Scottish culture (...) helped underpin the growing interest in Home Rule (...) and helped to infuse the crusade (...) with a new impetus and confidence" (Devine 2000, 608-9).

The Scottish Government's White Paper suggested that among the benefits of independence would be an impetus to greater cultural development in the nation (McGill 2013). The following passage appeared as one of the key planks of the "Yes" platform:

In an independent Scotland we will build on our cultural ambitions for Scotland. Our approach has been, and will continue to be, distinct from that of Westminster in that we recognise the intrinsic value of culture and heritage, and do not just value them for their economic benefit, substantial though that is. We view culture and heritage as fundamental to our wellbeing and quality of life. Our ambition is to build an independent nation where our cultural and historic life can continue to flourish. With independence we will have new powers over the economy to encourage our culture and creative sectors. And the process of becoming independent will, itself, stimulate new creativity and energy in Scotland (Scottish Government 2013b, 31).

This passage highlights the potential interplay (we might use Grundtvig's vekselvirkning) between the political, economic, and cultural aspects of Scottish life. And, notably, participants from the cultural sector, such as celebrities, got involved. For example, Alan Bissett, a Glaswegian author, playwright and performer wrote that the National Collective is

a great place for artists to come together and talk about the benefits (and possibly even some of the drawbacks!) of independence. Scotland is an incredibly creative country, which punches well above its weight in music, literature, theatre, the visual arts and fashion, and I want to be part of the exciting, new country to which these forces will contribute. 
National Collective is the focal point for that, helping transform Scotland with the power of imagination (National Collective 2014).

As Scott observes, independence movements often channel the efforts of poets, thinkers, artists and the politically active (Scott 2003, 317). As Grundtvig and Grundtvigians well-understood, the growth and deepening of a national cultural life can awaken a spirit within a people, embody and express values that lie at the heart of the people, give them something to cherish and therefore protect, affirm them as a people, and, as Craig (2003) and Riddoch (2013) suggest, build their self-belief, capacity and self-confidence in their national life. Questions of national self-confidence functioned with debate in arguments both for and against independence. For example, two prominent Scottish authors, under the auspices of the Saltire Society, produced contrasting pamphlets (McIlvanney 2014; Massie 2014). On one side, William Mcllvanney argued that the Scots ought to vote "Yes" to independence because they should believe in their own capacity to take full responsibility for themselves. On the other side, Allan Massie urged Scots to vote "No" to show their confidence in their ability to remain Scottish while prospering within the political union.

It is perhaps more typical of the contributions to political discourse from the arts sector than of those from party political sources that, while they may not be less politically-committed, they are more rooted in the story of the people, more expressive of fundamental values, more focused on stimulating public thinking and response and more inviting of dialogue - the virtues that Grundtvig sought for human society. The Scottish novelist and stand-up comedian A.L. Kennedy has, with some humour, commented, "Encourage cultural literacy in a nation bent on rediscovering itself after centuries of being silenced and you could end with an electorate that's confident, outspoken and energetic. Heaven forfend" (Kennedy 2011, online).

\section{Smallness - virtue or vulnerability?}

After the Danish multi-national composite state ended with the separation of Norway and the Duchies, leaving a rump state that had lost not only international power, physical land, and economic resources and something 
of its national self-understanding, Grundtvig wrote the following lines in "Foragter ej de ringe dage" (1837):

Do not despise the day of small things!"

Was said when Israel again

A temple to the God of all things

Was building in Jerusalem,

A shadow of the former one,

The temple of king Solomon.

$\cdots$

We build a house of humble state,

A shadow of God's mansions great

(VU, IX, 279-81). ${ }^{2}$

The reference in the poem to Zechariah 4,6-10 resonates with the situation in Denmark. The multi-faceted slogan "hvad udad tabes, det maa indad vindes" (Danmarkshistorien.dk, n.d.), originally used in relation to the heathland but also as a moral injunction, was itself an acknowledgement that Denmark's national future lay no longer in territorial or political grandeur. Smallness had been forced upon the Danish realm, but the reality of and the response to this diminution became a source of strengthening. "Grundtvig depicted a small, fair and satisfied land united by a common feeling," writes Lawler (Lawler 2004, 162). To this Danish understanding of itself is attributed much from many quotidian cultural assumptions (Hansen 1980) to a "fundamental mistrust of everything big" (Østergaard 1992, 168). Grundtvig was not simply acknowledging a politico-geographical reality; he was actively regarding smallness as a virtue. From his perspective, , the phrase "little Denmark" becomes less a quantitative assessment than a poetic expression of endearment, and it is that federnelandskerlighed that very often lies at the heart of national belonging. It is difficult not to hear the use of "little" without hearing a tone of affection, such as Scots often attach to Scottish word for "little", "wee".

Debates about Scottish independence frequently involve a comparison of Scotland with the "small" Nordic nations. Indeed, the Scottish Government explicitly, within its proposals, refers to nations which resemble

2 Trans. Hansen 2000, online. 
Scotland, all of them Nordic (Scottish Government 2013b). It is therefore reasonable to reflect on how Danish and Nordic small-nationhood ${ }^{3}$ has developed, not least under the influence of Grundtvig's thinking, with smallness being not only quantitatively descriptive but also a way of being in the world. Denmark and Scotland both have populations of around five to six million. Bailes, Thorhallsson and Johnstone suggests that all the Nordic states are "small" and that Scotland "fits well into their range," if we consider the variables of population, territory, GDP and military capacity (Bailes et al. 2013,3-4). It is argued by some that if the Nordic nations can be independent of each other, there is prima facie no reason why Scotland should not be (and perhaps an implication that it ought to be). Smout suggests that

The reasoning seems to go like this: Scotland is a small northern nation and wants self-government; Denmark, Norway and Sweden are all small nations, and they enjoy self-government; given self-government or at least meaningful devolution, Scandinavian prosperity can be recreated in Scotland (Smout 1977, 17).

This argument responds to the suggestion that Scotland may be too small to be a viable nation. The literature on small nations, however, has moved from focusing on vulnerability to considering potential strengths. "Small nationhood need not be a liability nor a clear sign of sub-optimality," suggests Hjort and Petrie (Hjort and Pertri 2007, 7). As Panke adds that

3 There is no simple, singular, unifying, multi-faceted and multi-contextual definition of what constitutes a "small nation" (Archer and Nugent 2002; Blandford 2013 , 9). While physical territory or population size or political structures may be relevant considerations, they are not defining in themselves and exceptions will be apparent. Other perspectives might be the power that the nation exercises relationally, its status in the eyes of other state or indeed non-state players, the resources available to it, its effectiveness in achieving its objectives in the world, or simply its self-understanding. Such factors may shift or be contextual or operate differently simultaneously. Self-identification as a small state may reflect the widely held understanding of the people or it may come, perhaps more significantly, from the political elite of the nation (Kristjansson and Cela 2011). Hjort and Petrie suggest that it is "mostly a general intuition rather than a clearly defined analytical tool" $(2007,3)$, a constructivist question rather than an objective one (Hey 2003, Thorhallsson 2006). 
"smaller states can compensate for size-related difficulties through institutionalized learning and through the possession of expertise" (Panke 2011, 137), bringing the flexibility and adaptability of which Katzenstein (1985) and Keating and Harvey (2014) write.

Different elements of small nationhood are important not just for the purposes of definitions but also because they express something of selfidentity and behavioural intention. In adopting a small nation self-identity, a nation may be engaging not only in an internalised process, but it also may be calling other nations to share in this understanding of what it is (Kristjansson and Cela 2011, 7). The late Donald Allchin, who rejoiced in the gift of Grundtvig to the wider world and celebrated Welsh cultural heritage, wrote of small nationhood:

In Denmark I learnt that a small nation is not the same as a large nation. (...) In the twentieth century the devastating effects of the pretensions of large nations, particularly when they become imperial or totalitarian or both, have been so evident, that many people seem afraid to speak or think of nationality at all. But national identity will not go away, even though we pretend it is not there. Certainly the nationalism of large nations which define themselves mostly in terms of their economic or military power, their capacity to control and dominate other nations, is something which itself needs to be very strictly scrutinised and controlled. (...) But the situation of a small nation (...) is totally different. It cannot, even if it wants to, define itself in this way. Its economic power is very limited; its military power negligible. It cannot dominate others; it has to learn to live in relationships of interdependence with them. Its definition and awareness of its national identity will necessarily be more internal than external, to do with shared memories and shared traditions, common experiences and common insights, usually conveyed and embodied in a shared language, whose very existence is often threatened in our age of mass-culture (Allchin 1992, 15).

Allchin insightfully draw attention to the issue of power. Instead of powerfulness, "small nations" should embrace "kærlighed, fredelighed, manglende erobrelyst, tro på en gudgiven lykke, beskedenhed, som afløses af mod og sejhed, når ydre provokationer bliver for nærgående" (LundgreenNielsen 1992, 78), to facilitate empowerment and to act as a dispassion- 
ate friend to the world community. As Jørgensen suggests, small nations should find "their strength and (...) self-respect from other things than the naked exercise of power" (Jørgensen 1993, 92-93). Though we may now distance ourselves from Grundtvig's notions of the special election of the Danish nation and people, Jørgensen suggests that he believed that this role was rooted in the "vulnerability of the Danish people (...) just as, once upon a time, the Israelite people became a witness to the fact that God is strong among the weak" (Jørgensen 1993, 96). Today, many small nations prove able to defend their own interests (Panke 2010) and, more altruistically, play the roles of mediator and peacemaker. They often prioritize development aid and champion environmental concerns and human rights. For example, when the Icelandic foreign minister addressed the UN General Assembly in 2007, she referred to her nation as

a small, dynamic state without a military (...) [I]t is our natural inclination to look for the peaceful settlement of disputes within the international community. (...) The Nordics have a reputation for being bridge builders - trusted mediators in complex situations (Gísladóttir 2007, online).

Then, Grimsson suggests that "a small country is well placed to be a creative political laboratory, a fertile ground for initiatives, a bearer of new ideas, an initiator of new thinking" (Grimsson 2008, 4).

It made sense to many in the debate that as a small nation, an independent Scotland would have had the potential to adopt these types of roles. The so-called Nordic model rooted in communitarian social understanding was held to resonate well with the dominant Scottish political and social philosophy. Olaffson suggests that "the citizen of a small state has a better possibility to influence decision making than a citizen of a larger state" (Olaffson 1998, 14).

Both Denmark and Scotland have, even today, a high degree of demographic homogeneity, and are often characterised as narrow in attitudes and perspective (Philip 2013) and as exclusive, though neither feature is the peculiarity of only smaller nations. "For some, small is beautiful, for others small means petty, mediocre, and tedious," writes Østergaard (Østergaard 2006, 93), noting Schwartz's piece (Schwarz 1985), which links smallness with hygge and an alleged related exclusiveness (Østergaard 
2006 , 92). There's no denying that cultural closeness of a relatively homogeneous national population can have negative effects. Negative effects, however, are not inevitable, and they are often outweighed by positives. As I pen this article, I hear in my mind a familiar popular Scottish chorus of welcome sung during the opening ceremony of the Commonwealth Games Glasgow 2014:

Come in, come in it's nice to see you

How's yersel' [yourself], yer looking grand

Tak a seat and ha'e a drammy [glass of whisky]

Man, yer welcome, here's my hand.

(Stewart, online)

Such expressions of traditional welcome can be stereotypical and sentimental and easily derided, but it is surely arguable that small nations, perhaps with a deep sense of internal community, can be open and hospitable societies whose welcome extends to incomers. A recent survey conducted by Oxford University Migration Observatory reported that Scottish attitudes to immigration were less likely than English attitudes to endorse a reduction in immigration and less likely to regard immigrants as illegal immigrants. Only $22 \%$ of the survey respondents believed that an independent Scotland would actually be less open to immigration (Brocklehurst 2014). Smaller nations might attribute this attitude to special demographics; Scotland has a more ageing population and different labour market needs than England. Larger nations might have a stronger sense of their insularity, defining themselves against other large nations and, in the case of England, against mainland Europe. Smaller countries, in contrast, define themselves significantly against large nations, as Scotland does its English neighbour.

\section{Conversation in heart and head}

The independence referendum campaign in Scotland largely lacked any direct reference to either the sovereignty argument around nationhood or an ethno-cultural appeal to "Scottishness," while Grundtvig openly hoped that his nation would rediscover its history, culture, values, and 
mission. Davies writes, "They [the Danes] had largely lost touch with their national past, and thereby lost the chief spur to self-reliance and co-operative effort" (Davies 1944, 6). She implies that the Welsh had lost touch, too. Grundtvig's view reflects a common nationalist process, which we see in A.D. Smith's analysis of nationalist programmes. He defines them collectively as:

a summons to the people, mobilizing the members of the community, tapping their collective emotions, inspiring them with moral fervour, activating their energies for national goals, so as to reform and renew the community (Smith 1999, 178).

With his emphasis on the place of love in the human, Grundtvig's national commitment is rooted in federnelandskarlighed, which is something more deep-seated than a constitutional duty or loyalty. Why might it be that the official pro-independence campaign in Scotland largely lacked such sentiment? Political leaders were certainly consciousness of the developing plurality of Scottish society, and they were doubtless reluctant to engage in a debate with ethno-cultural undertones. They regarded appeals to history as inevitably backward looking and inappropriate to a nation contemplating its future. Evidence shows, however, that the Scottish population in general (Leith and Soule 2012) held a rather "thick" view of national identity (Kohn 1944, 331).

It is easy to note also that questions of national identity were affected by pre-occupations with short term interests that have to be answered while holding on to the possibility that a wider and deeper debate is required. Davies writes:

One of the most disheartening features of the crisis [the seizure by Britain of Danish ships, the surrender of Norway to the Swedish crown, the 1813 State bankruptcy] was that instead of being concerned with what they could do to help their country, most people seemed concerned only with snatching some temporary advantage for themselves (Davies 1944, 9).

The Scottish debate, however, rarely extended beyond the narrow confines of personal or even public finances to a broader political agenda. 
Grundtvig, while scarcely a political radical, particularly in his earlier years, was not uncritical of the Danish social order nor lacking in vision of what a more just Danish society might look like. In his Danmarks Trøst (Langt højere Bjerge), he expresses his hope for a Danish society in general when he writes, "Naar faa har for meget og Færre for lidt" (VUVII, 346). The beloved Scottish poet Robert Burns expressed similar sentiments in The Ronalds of the Bennals when he contrasted those "weel stockit in means" (well stocked in means) and those without means (Burns 1780, 189-90).

\section{Looking North}

The referendum debate clearly raised and renewed concerns that Scotland remain a more socially and economically just society. Social justice and economic independence and how the two relate opened the door for thoughts about a stronger relationship between the Scots and the Nordic world. Indeed, the debate led some thinkers in Scotland to appropriate Grundtvig's idea of the North!

George Reid, a former deputy Presiding Officer of the Scottish Parliament with a SNP background, asserted Scotland's affinity with Nordic countries. He wrote, "The truth is, that of all the nations and regions that make up the United Kingdom, the Scots - by reason of history, culture, their environment - are probably the most Nordic in character. As a people we are naturally egalitarian and communitarian in spirit" (Newby 2009, 313). At the time of the founding of the Scottish Parliament, feeling spread in Scotland that the parliament should not mirror its counterpart at Westminster, which was thought to be too confrontational, insufficiently open in democratic terms, and uncommitted to consensus and bound by a rigid party system. These feelings were reflected in physical and ideological changes: officials reshaped the parliamentary into a horseshoe from its previous setup based on Westminster's opposite adversarial bench format, and they implemented transparent systems of access and consultation. Newby suggests that Nordic politics was a source of inspiration for these developments (Newby 2009).

Likewise, Scotland might be said to share the Nordic vision for a more fully comprehensive and cohesive system of social support to society and to individuals (Brandal et al. 2013; Denholm et al. 2007). Questions of 
sustainability or conservative concerns about neoliberal approaches have not dulled Scottish admiration for Nordic political methodology ( $\mathrm{Lu}$ and Olesen, n.d.).

Around the Scottish independence debate, but standing a little to the side of it, there has been formed in Scotland a network entitled Nordic Horizons which has been the arena in which Scottish academics, politicians, workers in the creative industries and the public in general have had an opportunity to explore Nordic initiatives in a range of fields such as transport, banking, and economics.

As I have suggested earlier, political leaders have been noticeably reluctant to draw on historical material in the independence debate, but they have affirmed that Scotland has had a "Norse" past and highlighted historical links with the Nordic world. Of course, it is not unusual for nationalist rhetoric (like other forms of political argument) to unearth a past that serves its interests. It is true that, though largely in a rather distant past, parts of Scotland were under Norse rule, and it is true that there have been significant trading links over the centuries and that there remains in some form or another a measure of "Nordicness" to Orkney and Shetland in particular. "The Orkney and Shetland Islands, along with Caithness (...) are identified primarily in terms of their Norse cultural heritage," asserts Heddle (Heddle 2010, 1). Shetland especially, even before becoming part of the northerly community of oil producers, has tended to turn its gaze upon its Norse past. Orkney in measure does so too: of Clouston's 1932 A History of Orkney, Hall observes that it "is unequivocally and unapologetically pro-Norse in its bias" (Hall 2010, 63).

This line of argument is fragile, save perhaps in the case of the Northern isles. Yet, it hints that while Scotland's past has been orientated in a southerly direction towards England and on, an important part of its future might lie in a northerly and easterly direction, towards Scandinavia.

Perhaps most powerful, however, is the Northern label and the image in the context of Scotland's hopes for its future (whether or not indeed it opts for autonomy). More broadly, internationally as well as domestically, this label "Nordic" is perhaps shorthand for "smaller, fairer and greener"? (Yale Conference on Baltic and Scandinavian Studies 2014). Imprecise it may well be; it has some capacity to encapsulate a view of the future.

The 2014 Yale conference on Baltic and Scandinavian Studies proposed a theme: "Reconnecting with the Nordic - Aspirational Identities in the 
Nordic Periphery." The title, particularly the word "aspirational," raises interesting issues in the Scottish context. To speak of "reconnecting" appeals to a sense of restoring a relationship that once was. And indeed those who want to reconnect with the Nordic world, while making a case in terms of current needs, nonetheless refer also to the re-establishment of a Northern community or commonwealth. The word "periphery" seems to open up the possibility that there may be a core to the Nordic world but that it stretches beyond that core in a more elastic and permeable way (as sometimes with Grundtvig's understanding of "Norden").

We might read "aspirational" in two distinct ways. There are those nations which sit on the periphery of the Nordic, amongst which we might count not only Scotland but the Baltic states, finding fresh connections and re-establishing historic ones: aspiring to be, or be acknowledged as, Nordics. As Reeploeg suggests, it may well be that "the changing geo-political landscape (of exclusion and inclusion of certain geographical areas within the Scandinavian or Nordic 'concept') is (...) an ongoing political project” (Reeploeg 2010, 116). There is aspiration also, however, to be "smaller, fairer and greener" and to be an environmentally conscious small nation aiding the developing world and promoting social and economic justice domestically.

From a Scottish nationalist perspective, the mere existence of the Nordic nations permits the assertion that small nations are capable of having an autonomous existence as states. Back in the 1940s, this issue was considered by Noëlle Davies' husband, who was impressed by that little country's [Denmark's] ability to govern itself (Davies 1947). This reaffirmation sits within the SNP Scottish Government's wider campaign for Scottish independence, which asserts, "Only independence will allow Scotland to build its own relationship with structures like the Arctic Council, Nordic Council and Nordic Council of Ministers, and to ensure that Scotland's own national interests are directly represented" (Scottish Government 2014b). The possible responses of the governments of these potential partners to approaches by an independent Scottish government are however difficult to know or anticipate, given the reluctance of UK partners to comment in ways that might contribute to the debate about Scottish independence.

Scottish re-orientation towards the Nordic world depended in part upon the outcome of the referendum to determine the extent of political 
powers. The failed referendum, however, has not drained the political and intellectual energy that was generated to foster an on-going exploration of how Scotland and its Nordic neighbours might learn and collaborate to find solutions to common problems.

\section{New neighbourliness}

In the aftermath of the vote, a more significant issue will be relations with the rest of the United Kingdom and, in particular, England. The question of how to re-establish a healthy relationship with the neighbouring strong and sometimes dominant power was, of course, a recurrent issue that Grundtvig wrestled with. He was always at the very least wary over Prussia's pre-occupation with itself and ambitions beyond itself (LundgreenNielsen 1992, 113). A new relationship with the Nordic world obviously need not imply a negative change in the relationship with England. To the contrary, as Bailes suggests, Nordic alignment "could both reinforce [the $\mathrm{rUK}^{4}$ relationship] politically (...) and help balance it with a societal/cultural community that fostered Scotland's new small-state values" (Bailes 2013, 16).

If Scotland had voted for independence, there would have been a consequent, sustained and intense period of negotiation. Now, in the aftermath of a "No" decision, leaders will consider new relationships with the EU, NATO, and other international bodies as well as specific alliances. Davies recalls a passage from Grundtvig's writing in which dependence is held together with freedom. She writes, "Both small and great nations, if they wish to live and work fruitfully, must reconcile themselves to a certain interdependence, just as the head and all the members of a body must do" (Davies 1944, 31).

Political, economic, social, cultural, institutional and familial links between Scotland and its southerly neighbour are strong, even if the relationship has varied from close and warm to less harmonious and occasionally difficult (Hassan 2010). The post-referendum relationship is now different but perhaps healthier and more mature than it has been. Hassan argues:

${ }^{4}$ UK is a term used to refer to what would remain of the United Kingdom if Scotland were to secede, i.e. England, Wales and Northern Ireland. 
The Scotland-England relationship is, for good and ill, one of the defining ways many Scots view the world. It ranges from football and rugby rivalry to history, politics, culture and identity (...) Anyone but England [a phrase commonly used to assert that a Scots' sports follower will support whichever team or player is not English] isn't about England at all, but about the limitations the Scots feel about themselves (2010, online).

Though he contributed much more besides to the development of modern Denmark, Grundtvig did a great service to his nation in holding up a mirror to the people. What kind of nation did they seek to be? What were their strengths and their resources - and their faults and failings? If Scotland considers the referendum and its outcome as a call to take greater responsibility for itself, including its shortcomings and weaknesses, then the referendum can provide a stronger foundation for a sound national self-understanding and confidence. O'Toole writes, "Do you want to have the safety net of an auld enemy to rage at when policies don't work and the world turns mean? Or do you prefer to look at yourself in the mirror, in all your glories and stupidities?" (2012, online)

\section{Abbreviations}

GEEG Steen Johansen og Henning Høirup (1848), Grundtvigs Erindringer og Erindringer om Grundtvig, Copenhagen.

SIRA (2013) Scottish Independence Referendum Act 2013, available online at: www.legislation.gov.uk/asp/2013/14/pdfs/asp_20130014_en.pdf. (Accessed. 26 May 2014)

US I-X Holger Begtrup (udg.) (1904-09), Nik. Fred. Sev. Grundtvigs Udvalgte Skrifter, I-X, Copenhagen.

UVI-VI P.A. Rosenberg (udg.) (1930), Nik. Fred. Sev. Grundtvigs Udvalgte varker, I-VIII, Copenhagen.

VUI-X Georg Christensen og Hal Koch, 1940-49, N.F.S. Grundtvigs Varker $i$ Udvalg, bind I-X, Copenhagen.

PS I-IX Svend Grundtvig et al. (udg.) (1880-1930), N.F.S. Grundtvigs Poetiske Skrifter, I-IX, Copenhagen. 
Grundtvig of Denmark - (Still?) A Guide to Small Nations

\section{Bibliography}

\section{Works by Grundtvig}

- (1820), "Danmarks Trøst. (Langt høiere Bjerge saa vide paa Jord.)" in $V U$ VII, 345-6.

- (1824), Brevveksling mellem Nørrejylland og Christianshavn in US IV, 229236.

- (1836), Det Danske Fiir-Klover eller Danskheden partisk betragtet in VU IV, 145-185.

- (1837), "Foragter ej de ringe dage" (Trans. J. Hansen, Mogens Lemvig) (2000) "Do not despise the days of small things", available at http://www3. telus.net/yen-hansen/hymns/m1h01.html. (Accessed 10 September 2014).

- (1844), "Skov-Hornets Klang mellem Skamlings-Bankerne" in GEEG, stk. 51, s. 76-78.

- (1847), "Lykønskning til Danmark med Det Danske Dummerhoved og Den Danske Høiskole" in UVVII, 181-270.

- (1848), "Folkelighed", (eng. trans.) in A.P. Thyssen (1983), "Grundtvig's Ideas on the Church and People up to 1824" in C. Thodberg and A.P. Thyssen (eds.), NFS Grundtvig. Tradition and Renewal, Copenhagen.

\section{Works by other authors}

Allchin, A.M. (1992), "The Outer Loss shall be the Inner Gain" in O. Davies and F. Bowie (eds.) Discovering Welshness Llandysul, Gomer.

Archer, C. and Nugent, N. (eds.) (2002), Small States and the European Union, New York.

Archifau, Cymru (n.d.), "Catalogue note on Dr Noëlle Davies' papers", (reference code GB 0210 NOEIES. National Library of Wales), Aberystwyth.

Baehr, Peter R. (1975), "Small States: A Tool for Analysis", in World Politics, Vol. 27, No. 3 (April 1975), 456-66.

Bailes Alison J.K. and Thorhallsson, Baldur (2013), "Instrumentalizing the European Union in Small State Strategies," in European Integration, 35(2), 99-115.

Bailes Alison J.K.; Thorhallsson, Baldur; and Johnstone, Rachel Lorna (2013), "Scotland as an Independent Small State: Where would it seek shelter?" in 


\section{JACK DYCE}

Stjórnmál \& Stórnsýsla / Icelandic Review of Politics and Administration, Vol. 9, Issue 1, 1-20.

Blandford, Steve (2013), "Introduction" in Steve Blandford (ed.), Theatre and Performance in Small Nations, Bristol.

Brandal, N.; Øivind, B. and Thorsen, D. (2013), The Nordic Model of Social Democracy, Basingstoke.

Bredsdorff, Morten (1974), "Digteren Goldschmidt og Grundtvig" in GrundtvigStudier 1974, 26-53.

Brocklehurst, Steven (2014), "Study looks at Scottish views on immigration", BBC News Scotland, 10 February 2014, available at: www.bbc.co.uk/news/ uk-scotland-26020982 (Accessed 24 February 2014).

Bugge, K.E. (1985), "NFS Grundtvig" in J.E. Thomas and B. Elsey (eds.), International biography of adult education, Nottingham.

Burns, Robert (1780/1875), "The Ronalds of the Bennals" in The Complete Poetical Works of Robert Burns, New York.

Centre for Confidence and Well-being (n.d.), "Key messages", available at: http:// www.centreforconfidence.co.uk/information.php?p=cGlkPTEwNQ, (Accessed 21 March 2014).

Craig, Carol (2003), The Scot's Crisis of Confidence, Edinburgh.

Currie, M. (2014), “Scottish independence: Is $£ 500$ the referendum deal breaker?”, BBC News Scotland, 22 January 2014, available at: www.bbc.co.uk/news/ uk-scotland-scotland-politics-25846914 (Accessed 22 January 2014).

Danmarkshistorien (n.d.) at: http://danmarkshistorien.dk/leksikon-og-kilder/vis/ materiale/myte-sagde-dalgas-hvad-udad-tabes-skal-indad-vindes/ (Accessed 12 September 2014).

Davies, D.J. and Davies, Noëlle (1947), Can Wales afford self-government?, Cardiff.

Davies, Noëlle (1944), Grundtvig of Denmark. A Guide to Small Nations, Caernarfon.

Denholm, Jane; McTurk, Tam and McDonald, David (2007), "Flying Nordic Kites" in Scottish Left Review, Issue 41, July/August 2007.

Devine, T.M. (2000), The Scottish Nation.1700-2000, London.

Devlin, Kate and McArdle, Helen (2014),"The sun rises on Glasgow's golden Games" in The Herald, 23 July 2014.

Dunleavy, P, Kippin, S and Suss, J (n.d.), Transitioning to a new Scottish state. Immediate set-up costs, how the handover will work, and the long-run viability of Scottish government (e-book), available at: http://eprints.lse.ac.uk/57708/1/ 


\section{Grundtvig of Denmark - (Still?) A Guide to Small Nations}

Transitioning-to-a-new-Scottish-state-PD-ebook.pdf (Accessed, 20 July 2014).

Eichberg, Henning (2006), “The Physical Culture Academy: People’s Education through Sport in Denmark" in Grundtvig-Studier 2006, 188-209.

Geertz, C. (1973), The Interpretation of Cultures, New York.

Gísladóttir, Ingibjörg Sólrún (2007), Ræða utanríkisráðherra á 62. allsherjarpingi Sameinuðu pjóðanna / Statement Minister for Foreign Affairs of Iceland at the Sixty-second Session of the General Assembly of the United. Nations, available at: utanrikisraduneyti.is/frettaefni/raed.urISG/nr/3858 (Accessed, 16 June 2014).

Grímsson, Ólafur Ragnar (2008),"Small States - Emerging Power? The Larger Role of Smaller States in the 21st Century”, Opening address by Ólafur Ragnar Grímsson, President of Iceland. Conference held by the Foreign Ministry of Iceland and the Centre for Small State Studies, University of Iceland, 16 June 2008.

Guibernau, Montserrat (2004), Catalan Nationalism. Francoism, Transition and Democracy, London.

Hall, Simon (2010), The History of Orkney Literature, Edinburgh.

Hansen, J.F. (1980), Cultural Assumptions in Danish Everyday Life, New York.

Hansen, Mogens Lemvig (2000), Do not despise the days of small things. [Forafter ej de ringe dage], available at: http:/www3.telus.net/yen-hansen/hymns/ m1h01.html (Accessed 10 September 2014).

Hassan, Gerry (2010), The Auld Enemies Still?, available at: www.gerryhassan.com/ short-journalistic-essays/the-auld-enemies-still/ (Accessed 27 May 2014).

- (2010), The Auld Enemy, Season 1, episode 3 of Scotland's Story (TV series, 1984).

Heddle, Donna (2010), "The Norse element in the Orkney dialect" in Robert McColl Miller (ed.), Northern Lights, Northern Words. Selected Papers from the FRLSU Conference, Kirkwall 2009, Aberdeen, 48-57.

Heininen, L. and Southcott, C. (eds) (2010), Globalization and the Circumpolar North, Fairbanks.

Hey, Jeanne A.K. (2003), "Introducing Small State Foreign Policy" in Jeanne A.K. Hey (ed.), Small States in World Politics: Explaining Foreign Policy Behaviour, London.

Hjort, M. and Petrie, D. (ed.) (2007), The Cinema of Small Nations, Edinburgh. 


\section{JACK DYCE}

Jobbins, Siôn T (2008), "Why not a Welsh royal family?" in Cambria Magazine, January 2008, available at: www.sionjobbins.com/Welsh\%20Royalty\%20terfynnol.doc (Accessed 7 January 2014).

Jørgensen, Theodor (1993), "Reflections on Grundtvig and Germany" in Grundtvig-Studier 1993, 91-104.

Katzenstein, P. (1985), Small States in World Markets: Industrial Policy in Europe, Ithica and London.

Keating, Michael and Harvey, Malcolm (2014), "The Political Economy of Small European States: and Lessons for Scotland" in National Institute Economic Review, No. 227, February 2014.

Kennedy, AL (2011), “Scotland's cultural awakening is a terrifying prospect for politicians", in The Guardian, 9 October 2011, available at: www.theguardian.com/politics/2011/oct/09/scotland-cultural-awakening-terrifying-prospect-for-politicians (Accessed. 27 February 2014).

Kohn, H. (1944), The Idea of Nationalism, New York.

Korsgaard, Ove (2011), "Grundtvig's Philosophy of Enlightenment and Education" in Edward Broadbridge (trans), Clay Warren and Uffe Jonas (eds.), The School for Life. NFS Grundtvig on Education for the People, Aarhus.

- (2014), N.F.S. Grundtvig - as a Political Thinker, (Trans. E. Broadbridge), Copenhagen.

Kristjansson, Jakob Thor and Cela, Margret (2011), Iceland as a "powerful" small state in the international community. Has geopolitics, neo-liberalism and the size of state influenced and interacted in the Icelandic foreign ministers policy discourse after 2000?, (Working Paper 1-2011) Iceland.

Kruk, Sergei and Chakars, Janis (2010), "Agency, Awakening and the Audio-visual" in Central European Journal of Communication, 2010, 53-65.

Laffan, Brigid (1997), "Constitutional Change in the European Union: The Small-State/Large-State Issue from Ireland's Perspective" in Irish Studies in International Affairs, Vol.8 (1997), 69-79.

Lawler, Peter (2004), "Loyalty to the folkhem" in A. Linklater and M. Valler (eds.), Political Loyalty and the Nation State, London.

Leith, M.S. and Soule, D.P.J. (2012), Political Discourse and National Identity in Scotland, Oxford.

Lochhead, Liz (2003), The Colour of Black and White. Poems 1984-2003, Edinburgh.

Lu, Alexandra and Olesen, Lisa Sig (n.d.), The Danish Illusion: The Gap between Principle and Practice in the Danish Welfare System. Humanity in Action, avai- 


\section{Grundtvig of Denmark - (Still?) A Guide to Small Nations}

lable online at: www.humanityinaction.org/knowledgebase/59-the-danish-illusion-the-gap-between-principle-and-practice-in-the-danish-welfare-system (Accessed. 28 May 2014).

Lundgreen-Nielsen, Flemming (1992), "Grundtvig og danskhed" in Ole Feldbæk (red.), Dansk Identitetshistorie, III Copenhagen, 9-187.

- (1997), "Grundtvig as a Danish Contribution to World Culture" in Grundtvig-Studier 1997, 72-91.

Massie, Allan (2014), Nevertheless, Edinburgh.

Maxwell, Jamie (ed.) (2013), The Case for Left-Wing Nationalism, Edinburgh.

McGill, Hannah (2013), "Would independence give our artists wings?", in The Herald, 31 March 2013.

McIlvanney, William (2014), Dreaming Scotland, Edinburgh.

Mooney, G. (2014), "The Scottish Independence Debate: Class, Nation and the Politics of Criminal Justice" in British Society of Criminology Newsletter, No 74, 4-7.

Morris, S. and Brooks, L. (2014), "Scotland should vote for independence to be "beacon of social justice" in The Guardian, 22 July 2014, available at: http:// www.theguardian.com/politics/2014/jul/22/scotland-independence-beaconsocial-justice-welsh-nationalists (Accessed 10 September 2014).

National Assembly of Wales (2013), "Wales and the Scottish Independence Referendum". Research paper, No 13/064, National Assembly of Wales Commission, Cardiff.

National Collective (2014), "National Collective. Artists and creatives for Scottish independence. About us. What our members say", available at: http://nationalcollective.com/about-us/ (Accessed 22 February 2014).

Newby, Andrew G (2009), "'In Building a Nation few better examples can be found". Norden and the Scottish Parliament" in Scandinavian Journal of History, Vol. 34, No. 3, 307-329.

O'Toole, Fintan (2012) in The Times, 5 June 2012, available at: http://www. thetimes.co.uk/tto/opinion/columnists/article3435691.ece (Accessed $22 \mathrm{Fe}-$ bruary 2014).

Olafsson, B. (1998), Small States in the Global System: Analysis and Illustrations from the Case of Iceland, Aldershot.

Panke, D. (2010), Small states in the European Union: Coping with Structural Disadvantages, London.

- (2011), "Small states in EU negotiations: Political dwarfs or power-brokers" in Cooperation and Conflict, 46(2), 123-143. 
Patriarca, Silvana and Riall, Lucy (eds.) (2011), The Risorgimento Revisited, Basingstoke.

Philip, Susan (2013), "Challenging Racial Categorisation through Theatre: English-language Theatre in Malaysia" in Blandford, Steve (ed.), Theatre and Performance in Small Nations, Bristol.

Reeploeg, Silke (2010), "Intercultural Opportunities and Regional Identity: Nordic Voices in Scottish Literature"” in eSharp, Issue 15, 112-132.

Raun, Toivo (2003), "Nineteenth- and early Twentieth Century Estoninan Nationalism Revisited" in Nations and Nationalism, 9(1), 129-47.

Rerup, L. (1993), "Grundtvig and 19th Century Nationalism” in Schjørring, J.H. (ed.) National Identity and International Community, 16-26.

Riddoch, Lesley Blossom (2013): What Scotland needs to flourish, Edinburgh.

Riley-Smith, Ben (2014), "Independence "will cost Scottish families $£ 600$ each"” in The Telegraph, 26 May 2014, available at: http://www.telegraph.co.uk/ news/uknews/scottish-independence/10855873/Independence-will-costScottish-families-600-each-Treasury-warns.html. (Accessed12 June 2014).

Schwartz, J (1985), "Letter to a Danish Historian” in Den Jyske Historiker 33, $123-4$.

Scott, Paul Henderson (2003), Scotland Resurgent: Comments on the Cultural and Political Revival of Scotland, Edinburgh.

Scottish Government (2013a), "Scotland's Future: from the Referendum to Independence and a Written Constitution”, Edinburgh, available at: www.scotland.gov.uk/Resource/0041/00413757.pdf. (Accessed 11 September 2014).

- (2013b), "Scotland's Future: Your Guide to an Independent Scotland", Edinburgh, available at: www.scotland.gov.uk/Resource/0043/00439021.pdf. (Accessed 11 September 2014).

- (2014a), "Scotland's place in Northern Europe", Press release on the speech of the External Affairs Secretary at the Arctic Connections Conference, hosted on behalf of the Scottish Government by the European Policies Research Centre at Strathclyde University, Glasgow, 10-11 June 2014.

- (2014b), "Nordic Baltic Policy Statement", Edinburgh, available at: http:// www.scotland.gov.uk/Publications/2014/03/1424 (Accessed 12 September 2014).

Simon, Erica (1998), And the Sun Rises with the Farmer. The Philosophical History of the Nordic Folkhighschool (trans. Kathryn Parke), Florence/MA, available at: http://www.peopleseducation.org/resource-center/and-the-sun-rises-withthe-farmer/ (Accessed 19 February 2014). 


\section{Grundtvig of Denmark - (Still?) A Guide to Small Nations}

Smith, A.D (1991), National Identity, London.

- (1999), Myths and Memories of the Nation, Oxford.

Smout, Christopher T. (1977), “The Scottish Identity” in R. Underwood (ed.), The Future of Scotland, London.

Stewart, Andy, In the land of Caledonia, available at: http://www.incallander. co.uk/ladesongs/song58.htm (Accessed 17 February 2014).

Thaning Kaj (1972), Grundtvig, Copenhagen.

Thorhallsson, B. (2006), "The Size of States in the European union: Theoretical and Conceptual Perspectives," in European Integration 28(1), 7-31.

Thorhallsson, Baldur and Kattel, Rainer (2012), "Neo-liberal small states and economic crisis: lessons for democratic corporatism" in Journal of Baltic Studies 2012, 1-21.

Thyssen, A.P. (1983), "Grundtvig's Ideas on the Church and People up to 1824" in C. Thodberg and A.P. Thyssen (eds.) N.F.S. Grundtvig. Tradition and Renewal, Copenhagen.

University of Edinburgh (2014), “The Celtic Revival in Scotland”. Conference program, Celtic and Scottish Studies, School of Literatures, Languages and Cultures 1-3 May 2014, available at: http://www.ed..ac.uk/schools-departments/literature-languages-cultures/celtic-scottish-studies/news-events/conf/ celtic-revival-conference/conference-programme (Accessed 10 April 2014).

Vind, O. (1999), Grundtvigs historiefilosofi, Copenhagen.

Whalen, Christopher (2007),"Haunted. English: The Celtic Fringe, the British Empire, and De-Anglicization" (review) in James Joyce Quarterly, vol. 45, Number 1, Fall 2007, 170-173.

Williamson, Roy, O Flower of Scotland, available at: http://news.bbc.co.uk/sportacademy/hi/sa/rugby_union/features/newsid_2650000/2650581.stm (Accessed 12 September 2014).

Wåhlin, Vagn (2006), "Popular, Religious and Social Movements: Recent Research Approaches and Qualitative Interpretations of a Complex of Historical Problems" in Grundtvig-Studier 2006, 132-87.

Yack, B. (1999), "The Myth of the Civic Nation" in R. Beiner (ed.) Theorizing Nationalism, New York, 103-124.

Yale Conference for Baltic and Scandinavian Studies (2014), "Reconnecting with the North - Aspirational Identities in the Nordic Periphery", available at: http://www.yale.ed.u/macmillan/balticstudies/ybss/stream13.html (Accessed 24 July 2014). 


\section{JACK Dyce}

Østergaard, Uffe (1992), “Denmark's Identity: European, Nordic or Peasant?” in Lise Lyck (ed.), Denmark and EC membership evaluated, London.

- (2006), "Denmark: A Big Small State. The Peasant Roots of Danish Modernity" in John L. Campbell, John A. Hall and Ove K. Pedersen (eds.), National Identity and the Varieties of Capitalism, London. 